\title{
Determinants of Operational Self-Sustainability of Microfinance Institutions in Vietnam*
}

\author{
Thanh Tam LE' ${ }^{1}$, Lan Phuong DAO², Ngoc Mai DO³ ${ }^{3}$ Thi Hoai Linh TRUONG ${ }^{4}$, \\ Thi Thuy Duong NGUYEN ${ }^{5}$, Chung Thuy TRAN ${ }^{6}$
}

Received: July 15, 2020 Revised: August 23, 2020 Accepted: August 28, 2020

\begin{abstract}
The purpose of this paper is to investigate the determinants of the Operational Self-Sustainability (OSS) of Vietnamese microfinance institutions (MFIs). This research uses both qualitative and quantitative research methods: (i) qualitative research was via in-depth interviews with ten microfinance practitioners, policymakers and researchers; (ii) quantitative research was conducted by using panel data of 34 MFIs in the period 2011-2015 with binary logistics and OLS regressions. Results are as follows: (i) MFIs' OSS in Vietnam are mainly determined by five key factors: portfolio at risk (PAR $>30$ ), capital structure, gross loan portfolio, scope of activities and legal form; (ii) OSS are most affected by legal status (social organizations have better OSS than formal MFIs or programs/projects), location (MFIs focus in one province have higher OSS than working nationwide or just in one district), capital structure (MFIs with more equity proportion have higher OSS); (iii) surprisingly, average loan size per borrower and age of MFIs do not have statistically significant correlation with OSS. The key recommendations are: (i) MFIs should focus on its professionality and increase its equity; (ii) related stakeholders such as State Bank of Vietnam should promote the enabling ecosystem for microfinance development to enhance poverty reduction and economic development.
\end{abstract}

Keywords: Capital Structure, Determinants, Microfinance Institutions, Operational Self-Sustainability, Portfolio at Risk

JEL Classification Code: G21, G28, D14, O16, O17

*Acknowledgements:

[1] This research is funded by National Economics University, Hanoi, Vietnam.

[2] This research was presented initially at 2018 International Conference on Finance, Accounting and Auditing (ICFAA2018) that was held in Hanoi, Vietnam, November 23, 2018. This research is a substantially revised and expanded version of the paper presented at ICFAA2018 conference. The authors have taken into account all the comments of Editors, Session Chairs and Reviewers in the revised manuscript. The authors greatly appreciate Editors, Session Chairs and Reviewers for their valuable comments of this research.

${ }^{1}$ First Author and Corresponding Author. Lecturer, Department of Commercial Banking, School of Banking and Finance, National Economics University, Vietnam [Postal Address: 207 Giai Phong Road, Hai Ba Trung District, Hanoi, 100000, Vietnam] Email: tamlt@neu.edu.vn ${ }^{2}$ Lecturer, Vietnam National University of Forestry, Vietnam. Email: phuongdl@vnuf.edu.vn

${ }^{3}$ Assistant Lecturer, International School, National Economics University, Hanoi, Vietnam. Email: dongocmai96@gmail.com

${ }^{4}$ Lecturer, Department of Commercial Banking, School of Banking and Finance, National Economics University, Vietnam. Email: linhth@neu.edu.vn

${ }^{5}$ Lecturer, Department of Public Finance, School of Banking and Finance, National Economics University, Vietnam. Email: duongnt@neu.edu.vn ${ }^{6}$ Lecturer, Department of Economic Mathematics, School of Banking and Finance, National Economics University, Vietnam. Email: thuytc@neu.edu.vn

(c) Copyright: The Author(s)

This is an Open Access article distributed under the terms of the Creative Commons Attribution Non-Commercial License (https://creativecommons.org/licenses/by-nc/4.0/) which permits unrestricted non-commercial use, distribution, and reproduction in any medium, provided the original work is properly cited.

\section{Introduction}

Poverty has always been a significant issue, not only of the poor countries, but also a global issue (Brau \& Woller, 2004; Nguyen \& Nguyen, 2019). Microfinance (MF) plays a very important role for economic development, especially the reduction of poverty and social development in developing countries (ADB, 2000; Brau \& Woller, 2004; Chowdhury, 2009; Ledgerwood et al., 2013; Mago, 2014). From the mid-90s, the Grameen Bank, ACCION, and Card Bank model in the world have proved that MF's activities can thrive and serve the poor without subsidies. Besides, some of the non-government and charity organizations have noticed that their growth is limited due to the scarcity of funds, therefore sustainability becomes the essential requests for MFIs (Ledgerwood et al., 2013).

Over three decades of formation and development, MF in Vietnam has achieved success in contributing to the economic and social development; in particular, improving living standard for the poor. However, the sustainability of microfinance institutions (MFIs) is still problematic (Nguyen \& Le, 2013; Quach, 2005). Therefore, the sustainable development of MF is one of the hot topics of concern to MF's practitioners, managers as well as donors (Duflos \& Le, 2013; Ha, 2014; Nguyen \& Le, 2013), which should be 
targeted in the next process of integration and development and financial inclusion. The operational self-sustainability (OSS) reflects the relationship between operating income and total operating costs, which is the first step in reach overall sustainability. Other higher levels of sustainability are financial self-sustainability, (FSS) and institutional selfsustainability (ISS). Therefore, determinants of the OSS of MFIs in Vietnam and the solutions to help MFIs operate more sustainably in term of FSS and ISS are urgent issues that need to be addressed, especially in the context of comprehensive financial inclusion.

The objective of this research is to investigate the determinants of the OSS of Vietnamese MFIs in the period from 2011 to 2015. In order to achieve this objective, the following research questions will be answered:

- What is the OSS of MFIs?

- What are the determinants of the OSS of Vietnamese MFIs?

- How can Vietnamese MFIs improve their OSS?

\section{Literature Review}

\subsection{Microfinance, MFIs and OSS}

Microfinance is the provision of a broad range of financial services such as deposits, loans, payment services, money transfers, insurance for the poor and low-income households, individual businesses and their small businesses (Ledgerwood et al., 2013; Truong, Le \& Phan, 2020). This may be an important element in effective poverty reduction strategies as it is consistent with the accessibility and condition of the poor (ADB, 2000; Brau \& Woller, 2004; Ledgerwood et al., 2013). In addition, "microfinance" has been developed into the new term of "financial inclusion" a concept that is being considered to expand the development of a comprehensive financial program and creating a way for financial markets to better serve the poor (Ledgerwood et al., 2013). The advent of microfinance has been heralded worldwide and it has been widely regarded as an instrument of poverty reduction (Armendáriz \& Morduch, 2010; Brau \& Woller, 2004; Bystro, 2007; Chinomona \& Le, 2013; Mosley, 2001; Tsai, 2004).

MFIs are the providers of financial services for the poor - mainly are credit and savings - although some providers offer other services such as payment and insurance (Ledgerwood et al., 2013). As an organization with dual goal - social outreach goals and financial sustainability challenge for MFIs is to be sustainable and support poverty reduction simultaneously (Armendáriz \& Morduch, 2010). The well-documented and widely applauded achievements of microfinance are increasingly coupled with recognition of its limitations and the need to take a more holistic view on good outreach, financial sustainability and positive impacts on poverty reduction (Brau \& Woller, 2004; D'Espallier et al., 2011; Ledgerwood et al., 2013).

Sustainability can be viewed from many different angles, such as organization, management, and finance (Mahajan \& Nagasri, 1999). Financial sustainability is one of the important aspects of sustainable development, which is defined as the ability to generate income to cover all operating and financing costs and other expenses incurred, with profitability (Ayayi \& Maty, 2010; Meyer, 2002). Rhyne (1998) and Meyer (2002) confirmed that sustainability helps MFIs to have good funding for serving the poor in the long run. There are two levels of financial sustainability: operational self-sustainability (OSS) and financial selfsustainability (FSS).

The OSS ratio shows the relationship between operating revenues and operating expenses (including depreciation and provision for losses). Donors and MFI officers use this to assess whether or not an MFI has covered its operation costs. International practices show that, to achieve the sustainable long-term operation, OSS must be more than $120 \%$ (Bogan, 2012; Chinomona \& Le, 2013; Ledgerwood et al., 2013; Nadiya et al., 2012). Financial self-sufficiency implies the ability to cover all administrative costs, loan losses, financing costs from operating income after adjusting for inflation and subsidies and treating all funding as if it had a commercial cost (Rosenberg, 2007). According to Morduch and Haley (2002), if the institution is not financially self-sufficient, it cannot survive without subsidies as it would not be able to cover its costs of capital at market rates. However, calculation of FSS is tricky due to the differences in confirming inflation and opportunity costs.

\subsection{Determinants of MFIs' OSS}

OSS is determined by internal and external factors in the ecosystem. As per the literature review, originated from firm theory, bank capital channel and agencies theories, the key determinants of OSS are internal and external factors (Cull et al., 2007; Imboden, 2005; Ledgerwood et al., 2013; Mahapatra \& Dutta, 2016; Nadiya et al., 2012; Osotimehin et al., 2011). Of which, the key factors are:

Portfolio at risk (PAR): The PAR $>30$ days is the ratio of loans outstanding principal past due installments longer than 30 days over total outstanding loans. The higher PAR is, the higher the potential loss in revenues, the lower the OSS. Therefore, PAR has an adverse effect on the OSS of MFIs (Ayayi \& Maty, 2010; Cull et al., 2007). Research by D'Espallier et al. (2011) and Nadiya (2014) also found that many women customers are associated with low portfolio risk, lower credit losses, all of which contributed to higher OSS. 
Capital structure of MFIs: The correlations between capital structure of MFIs (measured by ratio of total equity divided by total assets) and OSS varies in different studies. Coleman (2007) shown a positive relationship between debt and sustainability, while Bogan (2012) confirmed a negative relationship between higher equity and OSS. However, Nadiya (2014) found no correlation between capital structure and the target of OSS.

Depth of outreach of MFIs to measure how deep MFIs reach those who have been unable to access formal financial services. The average loan size is a proxy for depth of outreach determined as the average gross loan portfolio divided by the number of active borrowers. The indicator of greater depth of outreach is smaller loans. This factor represents the orientation for the development of an MFI or deep access of an MFI, which means the ability of MFIs in reaching very poor clients (Christen et al., 1995). Adongo and Stork (2006), Gregoire and Tuya (2006), Mahapatra and Dutta (2016), and Nyamsogoro (2010) concluded that larger loans are related to higher cost efficiency and profitability. The studies by Nadiya et al. (2012) and Nadiya (2014) put forward the negative relationship between average loan size and OSS by assessing the empirical case of 50 MFIs in India in the period 2005-2009.

Age of MFIs measured by the number of years the MFIs have been operated. In firm theory, the firms with longer time of establishment will be more sustainable thanks to its cost and operational management experiences. However, if old firms do not innovate and improve to update the new management and IT application, they could not be competitive with the newly-established firms with cheaper and faster inputs. In practical experiences of MFIs, these two dimensions also demonstrate the same. Ayayi and Maty (2010); Bogan (2012); Crombrugghe et al. (2008); Cull et al. (2007); and Nadiya et al. (2012) shown that the older the MFIs, the higher the OSS thanks to its reputation to attract savings and managed cost efficiency. In contrast, Nyamsogoro (2010) presented the different view: OSS is not affected by the MFIs' age at all.

Other characteristics of MFIs (Gross Loan Portfolio, Scope of activities and Legal form of MFIs): These elements demonstrate the specific aspects of a MFI that affect the operational self-sustainability. The previous research by Nadiya et al. (2012) shows that formal MFIs in India are more sustainable and have higher OSS than semiformal ones. Besides, the scope of activities of MFIs and savings service providers of MFIs also influences the OSS of MFIs (Crombrugghe et al., 2008). Moreover, Crombrugghe et al. (2008) and Nadiya (2014) all confirmed that gross loan portfolio has the positive correlation with the OSS of the MFIs. As the total portfolio increases, MFIs will be able to increase their operating income so that the OSS will increase.

\section{Research Methods}

\subsection{Data}

In this study, secondary panel data is collected from financial reports of 34 MFIs from Microfinance Information Exchange (MIX) market data for five years from 2011 to 2015. MIX is the platform initiated by the World Bank for socially-responsible investors and policymakers focused on inclusive finance in emerging markets. All big and reputed MFIs are MIX members and provided information to them quarterly. Therefore, data source is reliable and comparable with international standard. The primary data are from indepth interview with ten microfinance practitioners, policy makers and researchers in Vietnam to understand the microfinance landscape and confirm the key characteristics of Vietnam microfinance institutions for explanatory variables in the research model.

\subsection{Research Model}

To analyze determinants of OSS of MFIs in Vietnam, binary logistics and OLS regressions are applied, with Stata software. Basing on the literature review and in-depth interview results, seven determinants of MFIs' OSS in Vietnam are proposed as the following formula.

$$
\begin{aligned}
\text { LnOSS }= & \beta_{0}+\beta_{1} \operatorname{LnPAR}>30+\beta_{2} \text { LnEAR } \\
& +\beta_{3} \text { LnALSPB }+\beta_{4} G L P+\beta_{5} A G E \\
& +\beta_{6} \text { LOC } 1+\beta_{7} \text { LOC } 2+\beta_{8} \text { LEGAF } 1 \\
& +\beta_{9} \text { LEGAF } 2+\mu
\end{aligned}
$$

Of which, the variables and hypotheses are summarized as in Table 1:

\section{Results and Discussions}

\subsection{Descriptive Statistics of the Variables}

Descriptive statistics of the variables of the model, except the dummies LOC (activity scope) and LEGAF (legal form) in Table 2, shows that in general, MFIs achieve operational sustainability (average value of OSS is 139.99).

However, the levels of OSS are very different among MFIs, with some of MFIs only reaching 39\%, while the highest OSS, which one MFI gained was $290 \%$. Other variables such as PAR, EAR, ALSPB, GLP, and $A G E$ have a large difference between the highest and lowest values and the high standard deviation, which shows a large difference between MFIs for observed indicators. 
Table 1: Dependent variables, explanatory variables and hypotheses in the research model

\begin{tabular}{|c|c|c|c|c|}
\hline Variable & Definition & Formula & Hypothesis & References \\
\hline$P A R>30$ & $\begin{array}{l}\text { Portfolio at risk } \\
(>30)\end{array}$ & $\begin{array}{l}\text { Overdue debts }>30 \text { days } \\
\text { Total outstanding loans }\end{array}$ & - & $\begin{array}{l}\text { Ayayi and Maty (2010); Cull et al. } \\
\text { (2007); D'Espallier et al. (2011); } \\
\text { Nadiya (2014). }\end{array}$ \\
\hline$E A R$ & Capital structure & \begin{tabular}{|l|} 
Total Equity \\
Total assets \\
\end{tabular} & + & $\begin{array}{l}\text { Bogan (2012); Coleman (2007); } \\
\text { Nadiya (2014). }\end{array}$ \\
\hline$A L S P B$ & $\begin{array}{l}\text { Average loans per } \\
\text { borrower }\end{array}$ & $\begin{array}{l}\text { Total outstanding loans } \\
\text { Number of borrowers }\end{array}$ & - & $\begin{array}{l}\text { Christen et al. (1995); Adongo and } \\
\text { Stork (2006); Gregoire and Tuya } \\
\text { (2006); Mahapatra and Dutta (2016); } \\
\text { Nyamsogoro (2010); Nadiya et al. } \\
\text { (2012); Nadiya (2014). } \\
\end{array}$ \\
\hline$A G E$ & Age of MFls & $\begin{array}{l}\text { Numbers of year of MFIs' operation } \\
\text { by the time of research }\end{array}$ & + & $\begin{array}{l}\text { Ayayi and Maty (2010); Bogan } \\
\text { (2012); Crombrugghe et al. (2008); } \\
\text { Cull et al. (2007); Nadiya et al. } \\
\text { (2012); Nyamsogoro (2010). }\end{array}$ \\
\hline GLP & $\begin{array}{l}\text { Gross loans } \\
\text { portfolio }\end{array}$ & & + & $\begin{array}{l}\text { Crombrugghe et al. (2008); Nadiya } \\
(2014)\end{array}$ \\
\hline LOC1 & $\begin{array}{l}\text { Scope of activities } \\
\text { of MFls }\end{array}$ & $\begin{array}{l}(=1) \text { if MFI operates nationwide; } \\
(=0) \text { if MFIs operate in } 1 \text { province or } \\
\text { within districts }\end{array}$ & + & $\begin{array}{l}\text { Ayayi and Maty (2010); Crombrugghe } \\
\text { et al. (2008); }\end{array}$ \\
\hline LOC2 & $\begin{array}{l}\text { Scope of activities } \\
\text { of MFIs }\end{array}$ & $\begin{array}{l}(=1) \text { if MFIs operate in the whole } \\
\text { province, } \\
(=0) \text { if MFls operates in one district } \\
\text { only }\end{array}$ & + & $\begin{array}{l}\text { Ayayi and Maty (2010); Crombrugghe } \\
\text { et al. (2008); Nadiya et al. (2012) }\end{array}$ \\
\hline LEGAF1 & $\begin{array}{l}\text { Legal forms of } \\
\text { MFls }\end{array}$ & $\begin{array}{l}(=1) \text { if MFIs operate in the semi- } \\
\text { formal form of microfinance } \\
\text { programs/projects, }(=0) \text { if MFIs } \\
\text { operate in the forms of Social Funds } \\
\text { or licensed MFIs }\end{array}$ & - & Nadiya et al. (2012) \\
\hline LEGAF2 & $\begin{array}{l}\text { Legal form of } \\
\text { MFls }\end{array}$ & $\begin{array}{l}(=1) \text { if MFIs operate in the form of } \\
\text { social funds, }(=0) \text { if MFIs operate } \\
\text { in the form of licensed MFIs or } \\
\text { programs/projects }\end{array}$ & + & Nadiya et al. (2012) \\
\hline OSS & $\begin{array}{l}\text { Operational Self- } \\
\text { sustainability ratio }\end{array}$ & $\begin{array}{l}\text { Operating income } \\
\text { Total operational expenses }\end{array}$ & & \\
\hline
\end{tabular}

Table 2: Descriptive statistics of variables

\begin{tabular}{|l|c|c|c|c|c|c|}
\hline Variable & Unit & Observation & $\begin{array}{c}\text { Minimum } \\
\text { value }\end{array}$ & $\begin{array}{c}\text { Maximum } \\
\text { value }\end{array}$ & $\begin{array}{c}\text { Average } \\
\text { value }\end{array}$ & $\begin{array}{c}\text { Standard } \\
\text { deviation }\end{array}$ \\
\hline OSS & $\%$ & 104 & 39 & 290 & 139.39 & 43.08 \\
\hline PAR & $\%$ & 104 & 0 & 224 & 4.80 & 29.72 \\
\hline EAR & $\%$ & 104 & 0 & 100 & 43.34 & 27.98 \\
\hline ALSPB & VND 1,000 & 104 & $1,458,31$ & $63,000,00$ & $5,207.81$ & 63.25 \\
\hline GLP & VND 1,000 & 104 & 983,601 & $2,400,000,000$ & $119,285,419.24$ & $328,052,477.28$ \\
\hline AGE & Year & 104 & 1 & 24 & 8.73 & 6.41 \\
\hline
\end{tabular}

Source: Statistics results from Stata based on financial reports of 34 MFIs period (2011-2015). 


\subsection{Multicollinearity Test and Heteroskedasticity Test}

Variance Inflation Factor (VIF) is used to test the phenomenon of correlation between independent variables. Table 3 shows $\mathrm{VIF}<10$, which means that no multicollinearity exists. $L n G L P$ and $L n A G E$, LnGLP and LOCl, LEGEF1 and $L E G A F 2$ have the level of correlation approximately 0.58 . However, these values are not significantly high for concluding the perfect multicollinearity problem. Other statistical tests for checking errors (heteroskedasticity, multicollinearity) were taken to confirm that: this model does not have these problems.

\subsection{Regression Results}

Following are the regression results, with two steps. The original regression result with all independent variables showed some insignificantly statistical relations. After removing the insignificant variables, the second regression result is summarized (see Table 4).

Table 3: Correlation matrix and variance inflation of the variables in the model

\begin{tabular}{|l|c|c|c|c|c|c|c|c|c|c|c|}
\hline & LnOSS & $\begin{array}{c}\text { LnPAR } \\
\mathbf{3} \mathbf{3 0}\end{array}$ & LnEAR & LnALSPB & LnGLP & LnAGE & LOC1 & LOC2 & LEGAF1 & LEGAF2 & \multirow{2}{*}{ VIF } \\
\hline LnOSS & 1.000 & & & & & & & & & & \\
\hline LnPAR>30 & -0.0678 & 1.000 & & & & & & & & & 1.12 \\
\hline LnEAR & 0.5365 & 0.0421 & 1.000 & & & & & & & & 1.08 \\
\hline LnALSPB & 0.0580 & 0.1056 & -0.0282 & 1.000 & & & & & & & 1.18 \\
\hline LnGLP & 0.1930 & 0.1474 & 0.0868 & 0.3275 & 1.000 & & & & & & 2.70 \\
\hline LnAGE & 0.0709 & 0.1748 & -0.0012 & 0.1131 & 0.5762 & 1.000 & & & & & 2.26 \\
\hline LOC1 & -0.0068 & -0.0298 & 0.0987 & 0.1622 & 0.5888 & 0.4319 & 1.000 & & & & 1.49 \\
\hline LOC2 & 0.2090 & -0.0476 & -0.1014 & -0.1193 & -0.1006 & -0.0961 & -0.4746 & 1.000 & & & 2.07 \\
\hline LEGAF1 & -0.2636 & -0.1362 & -0.0640 & -0.0400 & -0.2824 & -0.0595 & 0.0287 & -0.2335 & 1.000 & & 1.83 \\
\hline LEGAF2 & 0.3587 & -0.0335 & 0.1711 & -0.1496 & -0.0721 & -0.0551 & -0.1364 & 0.1595 & -0.5887 & 1.000 & 1.12 \\
\hline
\end{tabular}

Source: Statistics results from Stata based on financial reports of 34 MFIs period $2011-2015$.

Table 4: Estimation results of OSS determinants of MFIs in Vietnam

\begin{tabular}{|c|c|c|c|c|}
\hline & \multicolumn{2}{|c|}{ Original } & \multicolumn{2}{|c|}{ After removing the insignificant variables } \\
\hline Variable & Coefficient & P-value & Coefficient & P-value \\
\hline Intercept & -3.217808 & & -1.936556 & \\
\hline LnPAR $>30$ & $-0.0316416^{*}$ & $0.072^{*}$ & $-0.0279216^{*}$ & $0.059^{*}$ \\
\hline LnEAR & $0.3305043^{* * *}$ & $0.000^{* * *}$ & $0.326961^{* * *}$ & $0.000^{* * *}$ \\
\hline $\operatorname{LnALSPB}$ & $0.1341518^{\text {ns }}$ & 0.511 & Removed & \\
\hline LnGLP & $0.1194703^{*}$ & $0.081^{*}$ & $0.1150524^{* *}$ & $0.002^{* *}$ \\
\hline LnAGE & $0.0287681^{\mathrm{ns}}$ & 0.718 & Removed & \\
\hline LOC1 & $-0.148921^{\mathrm{ns}}$ & 0.464 & Removed & \\
\hline LOC2 & $0.381412^{* *}$ & $0.009^{* *}$ & $0.4097602^{* *}$ & $0.005^{\star *}$ \\
\hline LEGAF1 & $0.0594789^{\text {ns }}$ & 0.540 & Removed & \\
\hline LEGAF2 & $0.4691555^{\star * *}$ & $0.000^{* * *}$ & $0.4230861^{* * *}$ & $0.000^{* \star *}$ \\
\hline $\mathrm{R}^{2}$ & 0.4655 & $0.0000^{* * *}$ & $0.4550^{* * *}$ & $0.0000^{* * *}$ \\
\hline No of Observation & 104 & - & 104 & - \\
\hline
\end{tabular}

Note: ${ }^{* * *},{ }^{* *},{ }^{*}$ : statistical significance at $\alpha=1 \%, 5 \%, 10 \%$ ns: not statistically significant. 
Table 5: Summary of hypotheses and actual determinant factors with Vietnam case

$\begin{aligned} & \text { Dependent variable: Operational Self- Sustainability (OSS) } \\
& \text { Number of observations: } 104\end{aligned}$
\begin{tabular}{|l|c|c|c|}
\hline Factors & Expected sign & Actual sign & Hypothesis summary \\
\hline Portfolio at Risk (PAR>30) & $(-)$ & $(-)$ & Accepted \\
\hline Capital structure (EAR) & $(+)$ & $(+)$ & Accepted \\
\hline Average loan size per borrower (ALSPB) & $(-)$ & - & Rejected \\
\hline Gross loan portfolio (GLP) & $(+)$ & - & Accepted \\
\hline Age of MFIs (AGE) & $(+)$ & - & Rejected \\
\hline The scope of activities of MFIs (LOC1) & $(+)$ & $(+)$ & Rejected \\
\hline The scope of activities of MFIs (LOC2) & $(+)$ & - & Accepted \\
\hline Legal form of MFIs (LEGAF1) & $(-)$ & $(+)$ & Rejected \\
\hline Legal form of MFIs (LEGAF2) & $(+)$ & Accepted \\
\hline
\end{tabular}

Among the determinants of OSS, four factors are insignificant, including average loan per borrower ( $L n A L S P B)$, age of MFIs ( $L n A G E)$, scope of activities at the national or in one province ( $L O C 1)$, and legal form of MFIs - if semi-formal or a project/program (LEGAF1). These are relevant to the Vietnam case, with ceiling maximum loan size for microfinance clients by the policy (USD1,430 by March 2018, and up to USD2,150 from March onward), young age of MFIs (max 20 years such as TYM), only few MFIs operated in more than two provinces (two biggest MFIs, including CEP in 9/65 provinces and TYM in 13/65 provinces), and most of MFIs developed from project/ program forms (see Table 5).

Among significant factors affecting OSS, portfolio at risks of MFIs $(\operatorname{LnPAR}>30)$ is negatively related to OSS (coefficient $=-0.0279216)$. Other factors remain constant, if the quality of loan portfolio $(P A R>30)$ decreased, MFIs will have to increase loan loss expenses, which declined the OSS of MFIs. This result is consistent with previous studies by Ayayi and Maty (2010), Becker (2013), Nadiya (2014). In Vietnam, most MFIs have very low $P A R>30$ days $(1 \%)$, which is also consistent with in-depth interview results with microfinance CEOs and deputy CEOs in Vietnam. This suggests that MFIs maintain relatively good quality of the loan portfolio from which had a positive impact on the sustainability and profitability of the organization.

The coefficient of LnEAR is +0.326961 , which means that the ratio of equity to total assets affect positively the sustainability of MFIs. The study results showed that MFIs with lower leverage ratio (higher equity ratio over total asset) got better OSS. It came from the fact that owners of Vietnamese MFIs are mainly local people's committees or mass organizations, who did not request any dividend or profit sharing from MFIs. Therefore, cost of equity is almost zero. This result is consistent with previous studies by Nadiya (2014) and Bogan (2012).

LnGLP is positively correlated to OSS $(+0.1150524)$, which implies that total loan portfolio of MFIs has positively affected the sustainability of MFIs. The research results by Nadiya (2014) also showed a positive correlation between the total portfolio and OSS of MFIs. When the total portfolio increased, MFIs can increase income and reduce the cost per unit by economies of scale; therefore, OSS will be improved. Hence, in order to reach good operational sustainability, MFIs need to expand market share and increase total loan portfolios. This is consistent with in-depth interview results with policy makers and researchers in Vietnam, which confirmed that Vietnamese MFIs have only one income source from lending, with modest economies of scales.

Research results by Crombrugghe et al. (2008) also showed that there was impact of scope of activities provided in the locality of MFIs (LOCs) and facilities providing saving services of MFIs on the sustainability of an MFI. However, the level of impact depends on the different research context of different countries. For Vietnam, this correlation is quite strong (+0.4097602), as MFIs worked in wider locations (e.g. more than one province; in each province, work in more than one district) have stronger financial status and better economies of scale.

Similarly, with the positive correlation of LEGAF2 (0.4230861), it demonstrates that MFIs having legal form are more sustainable than MFIs operating in the form of program and projects MF or even the official forms. While previous studies by Nadiya et al. (2012) show that MFIs in India, which are official MFIs, are more sustainable, this study implies that semi-formal MFIs in Vietnam have more advantages to other forms in both costs and operation. In Vietnam, MFIs operate at the district or inter-commune levels. Most programs/projects MF are run by or in cooperation 
with political-social organizations, and funds from foreign donors or granted by local People's Committees. After 2010, Vietnam became a middle-income country; many cheap foreign funding sources have been cut down, while funds from the state budget were also reduced due to difficulties in the economic crisis. Formalizing MFIs is a right direction, as it allows MFIs to mobilize deposits better and have the sustainable funding sources than before. However, the costs for newly licensed MFIs in the first few years are significant, as they should apply various regulatory requirements such as capital adequacy ratio, required reserves, provision for loan losses, and other types of compliances from human resources, corporate governance. These requirements increase operating costs in the first period of formalization, thus badly affecting the operational sustainability in shortterm.

\section{Conclusion and Policy Implications}

\subsection{Conclusion}

The key findings from this analysis are (i) MFIs in Vietnam are not highly sustainable, and still dependent on funding sources from outsiders; (ii) on average, MFIs in Vietnam meet the international standard of OSS; however, the sustainable level among institutions are very different; (iii) MFIs reach high level of portfolio quality, but lower level of sustainability. Therefore, the five significant factors affecting OSS in Vietnam are in decreasing order of impacts:

First, legal form of MFIs: Semi-formal MFIs have more advantages in reaching OSS than program/project types and even the formal MFIs in term of costs, while licensed MFIs had to face with high compliance costs right after being licensed in the first few years. MFIs with licenses and microfinance programs have more difficulties in cost and benefit management than the middle-level of legal form MFIs - the social funds. For formal MFIs, the cost of compliance and transformation are still high compared to their capacities.

Second, scope of activities of MFIs: MFIs operating in the whole province got better economies of scale than MFIs in one district only and gained better OSS. The MFIs who operated on a relatively larger scale (within one province) have better capacity to be sustainable than within one district. However, if MFIs operated at national levels, their operations may not be as efficient as one province.

Third, capital structure: the lower the leverage ratio, the higher OSS. MFIs with more equity have better sustainability than the MFIs borrowing or getting deposits from the public. This is thanks to the fact that owners of MFIs did not get profit sharing at all, and MFIs are operated mostly under social enterprise form.
Fourth, total loan portfolio: the higher the total loan portfolio, the higher the OSS. It means that lending is still the main income source of MFIs, and larger loan portfolio allows MFIs to reach economies of scale.

Fifth, portfolio at risk $(\boldsymbol{P A R}>30)$ : the lower the credit risks, the higher the interest incomes and the lower the provision for loan loss, then OSS has been improved. MFIs with good quality loans could keep high return (from interest), while reduce the cost of credit provision and bad debt issues.

However, unlike previous studies, the factors that have no impacts on Vietnamese OSS are: average loan per borrower, age of MFIs, MFIs working in several provinces, and legal form of MFIs - if semi-formal or a project/program. These differences are consistent with underdevelopment landscape of Vietnamese microfinance institutions and confirmed with in-depth interview results.

\subsection{Policy Implications}

For improving the sustainability MFIs, contributing to the economic development and poverty reduction in Vietnam, the following implications are proposed:

\subsubsection{To Microfinance Institutions}

- Attracting more equity, especially from the private sector for non-profit purposes. As the regression result shows, equity has positive impacts on MFIs' sustainability, which then support the development of Vietnam. MFIs mainly work with low-income people for development purposes. Therefore, attracting more equity from the private stakeholders who have non-profitability as social objectives are very necessary, both from domestic and international communities. MFIs should share more information transparently on their operations and demonstrate their strong impacts on social development, actively look for charity or development funding sources.

- Strengthening operational and risk management according to international practices, including liquidity management, credit management, credit risk management, operational risk management, financial management, capital adequacy ratio management, etc., in order to decrease portfolio risks, ensuring that MFIs can operate safely and sustainably. This is also the solid foundation for MFIs to reduce the costs, increase revenues, and build strong reputation for attracting savers, investors and donors.

- Expanding the customer base extensively and intensively by diversifying financial products provision such as lending (flexible durations and payment periods according to clients' cash flow, risk-based interest rate decisions for clients), microinsurance, remittance, savings (various term savings, savings for different purposes such 
as education, emergency, healthcare, installment savings). The application of soft selling and upselling techniques should be applied, in parallel with non-financial products such as financial literacy, financial advices, etc. These are helpful for keeping microfinance existing clients and attract the new ones. This approach is also essential for ensuring no "mission drift" of MFIs in its commercialization and development.

- Developing a clear strategy for the scope of operations in accordance with the size and capability of MFIs development. If MFIs restrict scope of operations within few products or few operational areas, they will limit the ability to reach customers and increase market share, thus, affecting the sustainability of the organization. However, if MFIs extend their operation too fast, it will reduce the sustainability due to the increase of management and operation cost, while facing difficulties in competing to expand market shares with other stronger financial providers such as commercial banks, people's credit funds, other MFIs, and private money lenders.

- MFIs operating in the form of Programs/Project of MFIs should be converted into social funds, as this is currently the highest sustainable model. Social funds need to choose appropriate time to officially transfer to MFI after the legislation on microfinance activities be modified and improved. At the same time, social funds should also develop a plan and prepare carefully in all aspects such as personnel, finance before officially transforming to MFI. This will help MFIs to become active and overcome the difficulties and challenges when initially formalized to stand strong and grow.

\subsubsection{To Policymakers (State Bank of Vietnam, Ministry Of Finance and Related Government Agencies)}

The development of MFIs depends very much on the legal framework, particularly the regulations directly related to MFIs. The transformation of MFIs into formal MFIs is a right policy to guide these organizations in a professional manner. Based on the experience from other countries, after the conversion, most MFIs will have larger operational scale and be more efficient. However, in this research, licensed MFIs have lower level of OSS than social funds (semi-official MFIs). The current regulations are still costly to licensed MFIs, as they must adapt various prudential requirements for safety, and system transformation cost of changes. Therefore, the regulations customized for MFIs should pay more attention to its characteristics and development purposes, encouraging the faster formalization process for the whole microfinance sector and financial inclusion.

\section{References}

ADB. (2000). Finance for the Poor: ADB Microfinance Strategy. Mandaluyong, Philippines: Asian Development Bank. http:// www.adb.org/sites/default/files/financepolicy.

Adongo, J., \& Stork, C. (2005). Factors influencing the financial sustainability of selected microfinance institutions in Namibia. Namibian Economic Policy Research Unit (NEPRU) Research Report No. 38. Windhoek, Namibia: The Namibia Economic Policy Research Unit.

Armendáriz, B., \& Morduch, J. (2010). The Economics of Microfinance (2nd Ed.). Cambridge, MA: MIT Press.

Ayayi, A. G., \& Maty, S. (2010). What drives microfinance institution's financial sustainability. The Journal of Developing Areas, 44(1), 303-324.

Becker, A. (2013). Micro-management: constitutional and policy concerns arising from India's microfinance institutions (development and regulation) bill. Northwestern Journal of International Law \& Business, 33(3), 711-740.

Bogan, V. (2012). Capital structure and sustainability: an empirical study of microfinance institutions. Review of Economics and Statistics, 94(4), 1045-1058.

Brau, J. C., \& Woller, G. M. (2004). Microfinance: A comprehensive review of the existing literature. Journal of Entrepreneurial Finance and Business Ventures, 9, 1-26.

Bystro, H. E. (2007). The microfinance collateralized debt obligation: A modern Robin Hood? World Development, 36(11), 2109-2126.

Chinomona, R., \& Le, T. T. (2013). Microfinance outreach and the microfinance institutions (MFI) sustainability: Evidence from Vietnam. The East Asian Journal of Business Management, 3(1), 5-16.

Chowdhury, A. (2009). Microfinance as a poverty reduction tool: A critical assessment. UN Department of Economic and Social Affairs (DESA) Working Papers No. 89. New York, NY: UN Department of Economic and Social Affairs. https://doi. org/10.18356/e9ad576c-en.

Christen, R. P., Rhyne, E., Vogel, R. C., \& McKean, C. (1995). Maximizing the outreach of microenterprise finance: an analysis of successful microfinance programs. U.S. AID Program and Operational Assessment Report No. 10.

Coleman, K. A. (2007). The impact of capital structure on the performanceofmicrofinanceinstitutions.JournalofRiskFinance, 8(1), 56-71. https://doi.org/10.1108/15265940710721082

Crombrugghe, A., Tenikue, M., \& Sureda, J. (2008). Performance analysis for a sample of microfinance institutions in India. Annals of Public and Cooperative Economics, 79(2), 269-299.

Cull, R., Demirguc-Kunt, A., \& Morduch, J. (2007). Financial performance and outreach: A global analysis of leading micro banks. The Economic Journal, 117(517), 107-133. 
D’Espallier, B., Guérin. I., \& Mersland, R. (2011). Women and repayment in microfinance: A global analysis. World Development, 39(5), 758-772.

Duflos, E., \& Le, T. T. (2013). Microcredit interest rates. Microfinance Working Group's Bulletin, 19, 20-23.

Gregoire, J. R., \& Tuya, O. R. (2006). Cost efficiency of microfinance institutions in Peru: a stochastic frontier approach. Latin American Business Review, 7, 41-70.

Ha, D. V. (2014). The interactive relationship between credit growth and operational self-sustainability of People's Credit Funds in Mekong Delta region of Vietnam. Journal of Asian Finance, Economics and Business, 6(3), 55-65. http://doi.org/10.13106/ jafeb.2019.vol6.no3.55.

Imboden, K. (2005). Building inclusive financial sectors: The road to growth and poverty. Journal of International Affairs, 58(2), 65-86.

Ledgerwood, J., Earne, J., \& Nelson, C. (Eds.). (2013). The New Microfinance Handbook: A Financial Market System Perspective. Washington, DC: The World Bank.

Mago, S. (2014). Microfinance and poverty alleviation: An empirical reflection. Journal of Asian Finance, Economics and Business, 1(2), 5-13. https://doi.org/10.13106/jafeb.2014.vol1. no2.5.

Mahajan, V., \& Nagasri, G. (1999). Building sustainable microfinance institutions in India. Findev Gateway Paper No. 09, September.

Mahapatra, M. S., \& Dutta, S. (2016). Determinants of sustainability of microfinance sector in India. Journal of Rural Development, 35(3), 507-522.

Meyer, R. L. (2002). Track record of financial institutions in assisting the poor in Asia. ADB Institute Research Paper No. 49. Mandaluyong, Philippines: Asian Development Bank.

Morduch, J., \& Haley, B. (2002). Analysis of the effects of microfinance on poverty Reduction. NYU Wagner Working Paper No. 1014. New York: New York University.

Mosley, P. (2001). Microfinance and poverty in Bolivia. The Journal of Development Studies, 37, 101-132.
Nadiya M. (2014). Sustainability of Indian Microfinance Institutions: A Mixed Methods Approach. London, UK: Springer. DOI: 10.1007/978-81-322-1629-2.

Nadiya, M., Polanco, F. O., \& Ramanan, T. R. (2012). Dangers in mismanaging the factors affecting the operational selfsustainability (OSS) of Indian Microfinance Institutions (MFIs) - An exploration into Indian microfinance crisis. Asian Economic and Financial Review, 2(3), 448-462.

Nguyen, H. H., \& Nguyen, N. V. (2019). Factors affecting poverty and policy implication of poverty reduction: A case study for the Khmer Ethnic People in Tra Vinh Province, Viet Nam. Journal of Asian Finance, Economics and Business, 6(1), 315319. http://doi.org/10.13106/jafeb.2019.vol6.no1.315.

Nguyen, K. A., \& Le, T. T. (2013). Sustainability of microfinance institutions in Vietnam: facts and recommendations. Hanoi, Vietnam: Transport Publishing House.

Nyamsogoro, G. D. (2010). Financial Sustainability of Rural Microfinance Institutions (MFIs) in Tanzania. PhD thesis, University of Greenwich.

Osotimehin, K. O., Jegede, C. A., \& Akinlabi, B. H. (2011). Determinants of microfinance outreach in SouthWestern Nigeria: An Empirical Analysis. International Journal of Management and Business Studies, 1(1), 001-007.

Quach, M. H. (2005). Access to Finance and Poverty Reduction: An Application to Rural Vietnam. PhD thesis, University of Birmingham.

Rhyne, E. (1998). The Yin and Yang of microfinance: Reaching the poor and sustainability. MicroBank Bull, 2(1), 6-8.

Rosenberg, R. (2007). CGAP reactions on the Compartamos initial public offering: A case study on microfinance interest rates and profits. CGAP Focus Note No. 42.

Truong, T. H. L., Le, T. N. Q., \& Phan, H. M. (2020). Formal versus informal credit: Which is better in helping rural areas in Vietnam? Journal of Asian Finance, Economics and Business, 7(5), 119130. https://doi.org/10.13106/jafeb.2020.vol7.no5.119.

Tsai, K. (2004). Imperfect substitutes: The local political economy of informal finance and microfinance in rural China and India. World Development, 32(9), 1487-1507. 


\section{Appendix}

Appendix 1: List of Vietnam's Microfinance Institutions in the research

\begin{tabular}{|c|c|c|}
\hline & MFI name & Symbol name \\
\hline 1. & An Phu Development Fund & AN PHU \\
\hline 2. & Anh Chi Em Program & ACE \\
\hline 3. & Center for Development for the Poor Ha Tinh & PPC \\
\hline 4. & Center for Women and Community Development & CWCD \\
\hline 5. & Childfund Hoa Binh & \\
\hline 6. & Credit savings program - Women's Union, Phu Yen District, Son La & \\
\hline 7. & CSOD & \\
\hline 8. & Dariu & \\
\hline 9. & Fund for opportunity for women to work in Daknong province & DNOWEOF \\
\hline 10. & Fund for poor employees in Ba Ria - Vung Tau province & CAFPE BR-VT \\
\hline 11. & Fund for poor self-employed workers & CEP \\
\hline 12. & Fund for supporting women in Bac Kan province & BKF \\
\hline 13. & Fund for supporting women in economic development of Ben Tre province & BTWU \\
\hline 14. & Fund for supporting women in Lao Cai province & \\
\hline 15. & Golden Hand Program & BTV \\
\hline 16. & Ho Chi Minh City Women Union & HCMC WOMEN UNION \\
\hline 17. & Ho Chi Minh Women Supporting Economic Development Fund & CWED \\
\hline 18. & Hue Heart Foundation & $\mathrm{H} 4 \mathrm{H}$ \\
\hline 19. & M7 Microfinance Institution & M7MFI \\
\hline 20. & Microfinance Department - World Vision Vietnam & WV Vietnam \\
\hline 21. & Microfinance fund for community development & MFCDI \\
\hline 22. & Ninh Phuoc Women Development Support Fund & \\
\hline 23. & Small Business Development Center & SEDA \\
\hline 24. & Small Credit Fund For Housing Refurbishment, Da Nang & \\
\hline 25. & Soc Son Fund for the poor women & PNN \\
\hline 26. & Soc Trang Fund for Poor Women & \\
\hline 27. & Standard training & STU \\
\hline 28. & Thanh Hoa Microfinance Institution & Thanh Hoa MFI \\
\hline 29. & Tien Giang Provincial Women's Economic Development Assistance Fund & MOM \\
\hline 30. & Tinh thuong One Member Limited Liability Company & TYM \\
\hline 31. & VietED Microfinace Institution & VietED MF \\
\hline 32. & Women Development Fund of Dien Bien district & FWD \\
\hline 33. & Women Development Fund of Dien Bien Phu city & DBP CITY \\
\hline 34. & Women Development Fund, Quang Binh & \\
\hline
\end{tabular}

